\title{
THE EXCRETION OF ZINC IN HEALTH AND DISEASE
}

BY LAWRENCE T. FAIRHALL AND LYMAN H. HOYT

(From the Department of Physiology, Harvard School of Public Health, and the Medical Clinic, Peter Bent Brigham Hospital, Boston)

(Received for publication April 12, 1929)

During recent years increasing attention has been directed towards the occurrence of zinc as a normal constituent of animal tissues and fluids (1). Its wide distribution in foodstuffs and particularly its concentration in germ cells - the endosperm of wheat and the yolk of eggs, for example - and constant presence in milk points to a definite utilization. The fact that there is a more or less definite ratio of zinc to calcium in blood in the proportion of $7: 100$, and that zinc metabolism in animals has been shown to bear some relation to inorganic salt metabolism in general (2), leads to speculation as to the part it plays in the human organism.

For this reason it was felt desirable to secure further data regarding the excretion of absorbed zinc under conditions of disease as compared with the normal. It is interesting to note that man ingests in his food practically as much zinc as he does iron. Far the greater part is excreted through the intestine. A small amount, however, is absorbed and excreted through the urine and, as the latter is a better index of absorbed zinc, a series of analyses of urinary zinc under conditions of health and disease was carried out.

\section{EXPERIMENTAL}

Twenty-four-hour specimens of urine were collected from a number of healthy individuals and also from hospital patients suffering from various diseases such as nephritis, uremia, duodenal ulcer, tuberculosis and diabetes. In order to avoid incidental contamination with zinc from glassware, the urine was collected in Pyrex glass-stoppered bottles and evaporated to dryness and ashed in Pyrex dishes. The zinc was separated and determined by a turbidimetric method as the ferrocyanide (3). 
Various clinical pathological data were collected also for comparison with the zinc data. Blood studies included blood urea nitrogen determinations, red blood cell counts, white cell counts and hemoglobins. The presence or absence of edema was noted. Blood pressures and the degree of existing vascular disease were also recorded.

TABLE 1

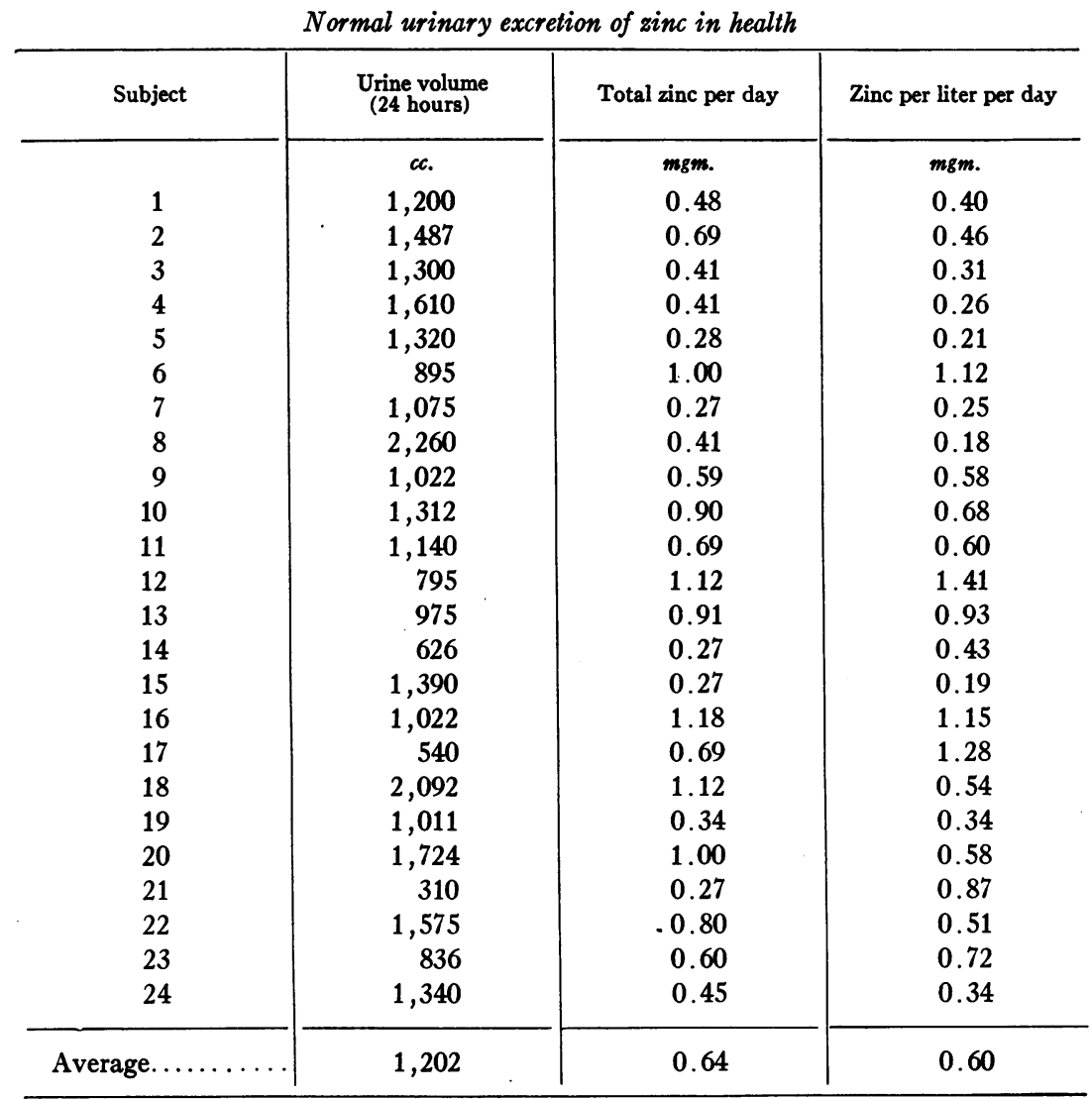

Urine examinations for albumin and casts were made. Owing to the fact that none of these figures show any significant correlation with the zinc output they have not been included in the tabulated data. The normal zinc content of the urine of the twenty-four healthy individuals is shown in table 1 , while the zinc content of the urine of the patients studied is shown in table 2 . 
TABLE 2

Urinary excretion of zinc in disease

\begin{tabular}{|c|c|c|c|c|}
\hline Subject & Type of disease & Urine volume & $\begin{array}{l}\text { Total zinc per } \\
\text { day }\end{array}$ & $\begin{array}{l}\text { Zinc per liter } \\
\text { per day }\end{array}$ \\
\hline & & $c c$. & $m g m$. & $m g m$. \\
\hline 25 & Nephritis & 310 & 0.17 & 0.55 \\
\hline 26 & Nephritis & 305 & 0.75 & 2.45 \\
\hline 27 & Nephritis & 321 & 0.40 & 1.25 \\
\hline 28 & Nephritis & 1,836 & 1.30 & 0.71 \\
\hline 29 & Nephritis & 516 & 0.70 & 1.36 \\
\hline 30 & Nephritis & 1,109 & 0.70 & 0.63 \\
\hline 31 & Nephritis & 588 & 0.25 & 0.43 \\
\hline 32 & Nephritis & 432 & 0.55 & 1.27 \\
\hline 33 & Nephritis & 205 & 0.65 & 3.17 \\
\hline 34 & Nephritis & 575 & 0.55 & 0.96 \\
\hline 35 & Nephritis & 298 & 0.70 & 2.35 \\
\hline 36 & Nephritis & 437 & 0.65 & 1.49 \\
\hline 37 & Nephritis & 148 & 0.87 & 5.88 \\
\hline 38 & Nephritis & 2,337 & 0.50 & 0.21 \\
\hline 39 & Nephritis & 880 & 0.60 & 0.68 \\
\hline 40 & Nephrosis & 558 & 0.54 & 0.97 \\
\hline \multicolumn{2}{|l|}{ Average.. . } & 678 & 0.61 & 1.52 \\
\hline 41 & Uremia & 1,540 & 1.65 & 1.07 \\
\hline 42 & Uremia & 760 & 0.87 & 1.15 \\
\hline 43 & Uremia & 1,310 & 1.45 & 1.10 \\
\hline \multicolumn{3}{|l|}{ Average... } & 1.32 & 1.11 \\
\hline 44 & Duodenal ulcer & 1,720 & 1.46 & 0.85 \\
\hline 45 & Duodenal ulcer & 1,010 & 0.38 & 0.38 \\
\hline 46 & Duodenal ulcer & 1,580 & 1.40 & 0.91 \\
\hline 47 & Duodenal ulcer & 1,510 & 0.65 & 0.43 \\
\hline 48 & Duodenal ulcer & 1,060 & 0.15 & 0.14 \\
\hline 49 & Duodenal ulcer & 950 & 0.45 & 0.47 \\
\hline 50 & Duodenal ulcer & 550 & 0.35 & 0.64 \\
\hline 51 & Duodenal ulcer & 1,750 & 0.45 & 0.26 \\
\hline 52 & Duodenal ulcer & 2,250 & 0.87 & 0.39 \\
\hline 53 & Duodenal ulcer & 835 & 1.05 & 1.26 \\
\hline 54 & Duodenal ulcer & 2,175 & 0.60 & 0.27 \\
\hline \multicolumn{3}{|l|}{ Average. . } & 0.71 & 0.54 \\
\hline 55 & Tuberculosis & 1,985 & 1.55 & 0.78 \\
\hline 56 & Tuberculosis & 850 & 0.70 & 0.82 \\
\hline 57 & Tuberculosis & 760 & 1.08 & 1.42 \\
\hline 58 & Tuberculosis & 1,000 & 1.24 & 1.24 \\
\hline \multicolumn{3}{|l|}{ Average. . } & 1.14 & 1.06 \\
\hline
\end{tabular}


TABLE 2-Concluded

\begin{tabular}{|c|c|c|c|c|}
\hline Subject & Type of disease & Urine volume & $\begin{array}{c}\text { Total zinc per } \\
\text { day }\end{array}$ & $\begin{array}{c}\text { Zinc per liter } \\
\text { per day }\end{array}$ \\
\hline & & $c c$. & $m g m$. & mgm. \\
\hline 59 & Pernicious anemia & 1,490 & 1.03 & 0.69 \\
\hline 60 & Pernicious anemia & 450 & 0.55 & 1.22 \\
\hline 61 & Lymphatic leukemia & 800 & 0.76 & 0.95 \\
\hline 62 & Cardiac & 978 & 0.27 & 0.28 \\
\hline 63 & Diabetes & 850 & 0.70 & 0.82 \\
\hline 64 & Gout & 1,190 & 1.35 & 1.14 \\
\hline 65 & Myxedema & 305 & 0.65 & 2.13 \\
\hline
\end{tabular}

\section{DISCUSSION}

None of the clinical pathological figures obtained from the urea nitrogen determinations, complete blood counts, blood pressure measurements, nor the presence or absence of edema, vascular disease, nor urinary findings were of significance with respect to the zinc output. Nor was the output of zinc greatly altered in cases of disease as compared with the normal amount excreted if the basis of comparison is total output. In the case of nephritic patients, the zinc concentration is increased above that of the normal because the total urinary output was small. Whereas the average normal daily output was $0.64 \mathrm{mgm}$. per 24 hours, or $0.60 \mathrm{mgm}$. per liter, with nephritic patients the average total daily output was $0.61 \mathrm{mgm}$. per 24 hours, or $1.52 \mathrm{mgm}$. per liter. Although this is a much higher concentration than normal, it should be noted that the total daily urinary output of the patients with nephritis studied represented but slightly over one-half that of the normal individuals. This was the direct result of the constant restricted low fluid intake which was part of the treatment. If the urinary volume output of the nephritic patients had not been restricted in this manner, there is the possibility that the total zinc excretion figure would have been affected, that is, if the average urine volume of the nephritic patients had been as great as the normal, it is a reasonable assumption that the total zinc output might have been increased in proportion. In any event, in terms of concentration alone, the urinary zinc of the nephritic patients was greater than that of the normal individuals.

Patients with duodenal ulcer show no great departure from the 
average for normal individuals. The average total daily excretion of the ulcer cases was 0.71 or $0.54 \mathrm{mgm}$. per liter per day.

In uremia and tuberculosis, the zinc content was distinctly higher than the average normal in every case examined. The average daily excretion of tuberculous patients was 1.14 or $1.06 \mathrm{mgm}$. per liter, while in uremia, the average daily excretion was 1.32 or $1.11 \mathrm{mgm}$. per liter. In these last two cases, therefore, the average zinc excretion was practically double the average normal excretion. Whether these differences are great enough to be of significance is a debatable question. With this as a clue, however, it might prove of interest to investigate the zinc metabolism of tuberculous patients more closely.

\section{SUMMARY}

An investigation of the urinary zinc excretion of twenty-four healthy individuals and of forty-one hospital patients showed that while no constant relation could be discovered between zinc output and the degree of anemia, or alteration in hemoglobin, blood cell count, urinary albumin or edema, the zinc output is somewhat different in nephritis and markedly accentuated in uremia and tuberculosis.

\section{BIBLIOGRAPHY}

1. Drinker, K. R., and Collier, E. S., J. Ind. Hyg., 1926, viii, 257. The Significance of Zinc in the Living Organism.

Lutz, R. E., J. Ind. Hyg., 1926, viii, 177. The Normal Occurrence of Zinc in Biological Materials.

Birckner, V., J. Biol. Chem., 1919, xxxviii, 191. The Zinc Content of Some Food Products.

Rost, E., Die Umschau, 1920, xxiv, 201. Zinc and Copper, Regular Constituents of the Humàn Body. (Abstr. in Chem. Abstr., 1929, xiv, 2034.)

Weitzel, A., Arb. a. d. Reichsgsndhtsamte., 1918, li, 476. Beiträge zur Bestimmung von Zink in organischen Stoffen.

Weitzel, A., Zentralbl. f. Physiol., 1914, xxviii, 766. Über das natürliche Vorkommen von Zink in Lebensmitteln und in den Ausscheidungen des Menschen.

2. Fairhall, L. T., J. Biol. Chem., 1926, lxx, 495. The Nutritative Value of Inorganic Substances. I. A Study of the Normal Zinc Metabolism with Particular Reference to the Calcium Metabolism.

3. Fairhall, L. T., J. Ind. Hyg., 1926, viii, 165. The Estimation of Zinc in Biological Material. 